\title{
Overwinter growth and survival of age-0 largemouth bass (Micropterus salmoides): revisiting the role of body size
}

\author{
James E. Garvey, Russell A. Wright, and Roy A. Stein
}

\begin{abstract}
How large size affects overwinter growth and survival of age-0 fish may vary as a function of food, predation, and energetic condition. During two winters in Ohio, we assessed how these factors affected growth and survival of varying sizes of age-0 largemouth bass (Micropterus salmoides) by combining a field survey $(N=2$ reservoirs) with multiscale experiments (reservoirs, ponds, outdoor pools). In our survey, more small ( $<100 \mathrm{~mm}$ total length) individuals died by spring in one reservoir than in the other. Similarly, when we stocked two reservoirs with marked age-0 largemouth bass in fall, mortality of small individuals was higher in one system overwinter, potentially due to differences in predation intensity. In ponds during two winters, size-selective mortality of small largemouth bass occurred in only two of eight ponds, potentially as a function of cannibalism. Varying ration in pools (starved, $0.5 \times$ maintenance, or $1.5 \times$ maintenance) did not affect survival, even though starved individuals lost substantial wet weight and energy content. Only when predators were present did small individuals die at high rates, although energy depletion may have contributed to predatory mortality. To increase the probability of overwinter survival, managers should seek to improve first-summer growth, reduce winter predation, and increase winter forage.
\end{abstract}

\begin{abstract}
Résumé : Chez le poisson d'âge-0, l'influence de la taille sur la croissance et la survie en hiver varie en fonction de la nourriture, de la prédation et de l'état énergétique. Pendant deux hivers en Ohio, nous avons cherché à déterminer comment ces facteurs influent sur la croissance et la survie de l'achigan à grande bouche (Micropterus salmoides) d'âge-0 de différentes tailles en combinant les résultats d'un relevé sur le terrain $(N=2$ réservoirs) à ceux d'expériences à diverses échelles (réservoirs, étangs et mares). D'après le relevé, le nombre de spécimens de petite taille (longueur totale $<100 \mathrm{~mm}$ ) morts au printemps était plus élevé dans un des deux réservoirs étudiés. Nous avons ensemencé en automne deux réservoirs en y lâchant des achigans marqués d'âge-0; dans ce cas aussi, la mortalité des petits sujets était plus importante dans un des deux réservoirs à la fin de l'hiver, l'écart étant peut-être dû à une différence d'intensité de prédation. Par ailleurs, nous avons étudié huit étangs durant deux hivers et nous n'avons constaté de mortalité chez les achigans de petite taille que dans deux d'entre eux; la mortalité observée pourrait avoir été due au cannibalisme. Nous avons soumis les populations des mares à des régimes alimentaires différents (jeûne, demi-ration d'entretien ou une fois et demi la ration d'entretien) : le régime alimentaire n'a pas influé sur la survie et ce, malgré une baisse considérable du poids humide et de la teneur énergétique chez les sujets soumis au jeûne. Chez les achigans de petite taille, la mortalité n'a été élevée que dans les mares où il y avait des prédateurs; la baisse d'énergie a toutefois pu contribuer à la mortalité par prédation. Pour augmenter les chances de survie de l'achigan, les gestionnaires doivent prendre des mesures pour améliorer la croissance des poissons en été et pour réduire la prédation en hiver, et augmenter les rations en hiver.
\end{abstract}

[Traduit par la Rédaction]

\section{Introduction}

Conventional wisdom holds that body size is strongly linked to growth and survival of early life stages (e.g., Miller et al. 1988). For larval and juvenile fishes, large size confers a host of advantages during a time when mortality is typically high, including reduced risk of predation through improved swimming ability (Christensen 1996), reduced vulnerability to gape-limited predators (Hambright et al. 1991), and reduced risk of starvation through enhanced foraging opportunities (Schael et al. 1991; Bremigan and Stein 1994). When food is scarce, large fish have abundant energy reserves relative to small counterparts (Isely 1981; Ludsin and DeVries 1997), thereby improving their survival. Both starvation and predation are important, often interacting during the first year of life to influence survival of small larval

Received September 8, 1997. Accepted March 25, 1998.

J14199

J.E. Garvey. ${ }^{1}$ Department of Biology, Queen's University, Kingston, ON K7L 3N6, Canada.

R.A. Wright. Department of Fisheries and Allied Aquacultures, Auburn University, Auburn, AL 36849, U.S.A.

R.A. Stein. Aquatic Ecology Laboratory, Department of Zoology, Ohio State University, Columbus, OH 43212, U.S.A.

${ }^{1}$ Author to whom all correspondence should be addressed. Present address: Division of Biology, Ackert Hall, Kansas State University, Manhattan, KS 66506, U.S.A. e-mail: jgarvey@ksu.edu 
and juvenile fishes (Rice et al. 1987), recruitment to later life stages, and, ultimately, cohort strength.

Starvation and, perhaps, predation may be especially important during the first winter when, for many fish, rapid summer growth and large fall size are necessary for survival (Post and Evans 1989; Cargnelli and Gross 1996). Hence, the first winter often is quite commonly viewed as a "critical period" determining year class strength of fishes (May 1974). As with other fishes, large fall size often improves winter survival of largemouth bass (Micropterus salmoides) (Miranda and Hubbard 1994a, 1994b; Ludsin and DeVries 1997). Although size-dependent energy depletion has often been suggested as the sole factor determining overwinter success (Gutreuter and Anderson 1985), predation has recently been identified as important (Miranda and Hubbard 1994b). Because small largemouth bass do not always suffer high mortality during winter (Kohler et al. 1993; Wright 1993), the size-specific effects of starvation and predation as well as other sources of mortality for largemouth bass (e.g., disease) may vary among systems and years.

As with many fish species, growth during the first year of life varies greatly for largemouth bass (Adams and DeAngelis 1987; Garvey and Stein 1998). Thus, understanding how size-dependent processes drive overwinter survival is especially important for predicting their recruitment to the second year of life. Our goal, then, was to determine $(i)$ if current models based solely on the interaction between size and energy depletion were sufficient for predicting overwinter mortality (e.g., Shuter et al.1980) or (ii) if models must incorporate other effects such as variable food availability and predation. We conducted a field survey plus experiments at multiple scales during the winters of 19941995 and 1995-1996 to assess the relative influence of size, food availability, predation, and energetic condition on growth and survival of juvenile largemouth bass. In our field survey, we explored how overwinter survival of largemouth bass varied between two Ohio reservoirs. In experiments in which age-0 largemouth bass were stocked into reservoirs and hatchery ponds, individuals were followed through winter in systems in which predators were abundant (reservoirs) or absent (ponds). We also conducted experiments in large outdoor pools to assess how food availability influenced overwinter survival.

\section{Methods}

\section{General}

Unless otherwise specified, all largemouth bass in surveys and experiments were (i) age- 0 and (ii) measured (nearest $1 \mathrm{~mm}$ total length) and weighed (nearest $0.1 \mathrm{~g}$, at least five individuals per 10-mm length class). Herein, age-0 begins when individuals hatch (usually May) and ends when the next year class hatches. For experiments, largemouth bass were obtained from Hebron State Fish Hatchery, Ohio (parental stock was obtained from Grand Lake St. Marys, Auglaize County, Ohio). In reservoirs and experiments, winter temperatures were quantified four or five times daily with a temperature data logger. Because energy depletion due to starvation may contribute to overwinter mortality (e.g., Oliver et al. 1979), we quantified energy content (kilojoules) of largemouth bass in experiments conducted in winter 1995-1996 using bomb calorimetry (see Rand et al. 1994 for specific methods). For each experiment, we quantified energy content of four to six largemouth bass per $10-\mathrm{mm}$ length class. Largemouth bass $>150 \mathrm{~mm}$ were verified as age- 0 by examining scales. When sample sizes were sufficiently large $(N>25)$, we determined how age (either age- 0 or age-1) varied as a function of the independent variable, length, using logistic regression (PROC LOGISTIC, SAS Institute Inc. 1985; Feinberg 1980). From this, we calculated the size-based probability of age and removed corresponding proportions of age- 1 individuals from distributions.

\section{Reservoir patterns}

We determined how variation in size of naturally produced largemouth bass influences their overwinter survival in two Ohio reservoirs, Knox Lake (225 ha, $19.2 \mathrm{~km}$ of shoreline, Knox County) and Pleasant Hill Reservoir (344 ha, $21.5 \mathrm{~km}$ of shoreline, Richland and Ashland counties). In summer 1994, these reservoirs contained high densities of age- 0 largemouth bass with widely varying fall sizes (50-200 mm). On 4 days during October 12-26, 1994, and 4 days during April 6-20, 1995, in Knox Lake, we collected largemouth bass by electrofishing (pulsed DC) littoral zones, sampling about $75 \%$ of the shoreline each day. Because different sizes of largemouth bass can occupy different depths, we sampled by driving the boat perpendicularly from deep $(>1 \mathrm{~m})$ to shallow (about $25 \mathrm{~cm}$ ) water. On November 11, 1994, and April 25 and May 5, 1995, in Pleasant Hill Reservoir, we electrofished littoral zones in a similar fashion for $100 \mathrm{~min} /$ date.

\section{Reservoir experiments}

To estimate growth and mortality, thereby improving control over our reservoir survey, we stocked two Ohio reservoirs (both with historically low densities of age-0 largemouth bass) with marked, hatchery-reared largemouth bass (see general methods) of different sizes in fall 1995. Stocking densities were based on naturally occurring densities of largemouth bass in Knox Lake in 1994 (about 1.5 age-0 largemouth bass/m shoreline, J.E. Garvey, unpublished data). In Kokosing Lake (65 ha, $7.5 \mathrm{~km}$ of shoreline, Knox County), we stocked 4905 small (76-94 mm) and 5954 large (95$150 \mathrm{~mm}$ ) age- 0 largemouth bass of which 65 and $58 \%$ of small and large size classes received left and right pelvic fin clips, respectively. In Clark Lake (40 ha, $4.5 \mathrm{~km}$ of shoreline, Clark County), we stocked 7500 small $(70-121 \mathrm{~mm})$ and 284 large (146-267 mm) largemouth bass marked with pelvic fin clips (as for Kokosing Lake). For the Clark Lake stocking, we also marked all large and $65 \%$ of small largemouth bass with fluorescent yellow or red plastic granules $(300 \mu \mathrm{m}$ in diameter) sprayed with pressurized nitrogen at $70 \mathrm{~g} / \mathrm{cm}^{2}$ (see Nielsen 1992). Colored grains embedded under scales were detected with ultraviolet light. Mortality was negligible; after $24 \mathrm{~h}$ in hatchery raceways, only one of 6850 spray-marked largemouth bass died. With the exception of the large size class in Clark Lake for which lengths of all individuals were recorded (nearest $1 \mathrm{~mm}$ ), we recorded lengths of about $10 \%$ of individuals. All individuals were measured for assignment to size classes.

Largemouth bass were stocked into Clark Lake and Kokosing Lake on October 26 and 27, 1995, respectively. Reservoirs were electrofished 1 week poststocking (1 day/reservoir) and during late April through early May 1996 (4 days/reservoir), sampling >70\% of the shoreline each day. In fall, density of age-0 largemouth bass was estimated with a Petersen estimate for a single mark-recapture (Ricker 1975). In spring, captured largemouth bass were finclipped; their abundances were estimated with a modified Schnabel estimate for multiple censuses (Ricker 1975). During fall and spring electrofishing, we sampled predator diets (all piscivorous fish $>250 \mathrm{~mm}$ ) with gastric lavage (Seaburg 1957). Diets were collected in fine-mesh bags, preserved in $95 \%$ ethanol, identified to species for fish and to family for invertebrates, and measured (nearest $1 \mathrm{~mm}$ ). If fish were digested beyond recognition, we iden- 
tified them to species using vertebral counts (Holland-Bartels et al. 1990).

\section{Pond experiments}

We conducted pond experiments during the winters of 19941995 and 1995-1996 to assess (i) the influence of size and food availability on overwinter survival without adult predators and (ii) mark retention. On October 19, 1994, we added 210-265 small (64-107 mm) and 105-135 large (115-179 mm) largemouth bass to each of four, 0.4 -ha hatchery ponds ( $1.5 \mathrm{~m}$ average depth, 300400 largemouth bass/pond; pond experiment A), recording lengths of all individuals. To provide additional forage, we added about 1700 fathead minnow (Pimephales promelas) (mean \pm 1 SD length $=63 \pm 7 \mathrm{~mm}$, mean weight $=2.7 \pm 1.0 \mathrm{~g}$ ) to each pond. On June 14,1995 , we slowly drained each pond over $24 \mathrm{~h}$ and then recovered largemouth bass. To compare our ability to recover small and large largemouth bass, we added $102( \pm 2)$ small and $100( \pm 2)$ large marked individuals to two ponds (about 200 largemouth bass/pond; pond experiment B) $24 \mathrm{~h}$ after pond experiment $\mathrm{A}$. We then drained these ponds over $24 \mathrm{~h}$, recovering largemouth bass in a similar fashion to pond experiment A.

On October 25, 1995, we conducted pond experiment C to parallel reservoir experiments (see reservoir experiment methods) by adding 200-300 small (73-122 $\mathrm{mm})$ and 25-50 large (142$268 \mathrm{~mm})$ largemouth bass with no fish prey to each pond $(N=4$ ponds, 250-325 largemouth bass/pond). To assess spray-mark retention, we stocked two of these ponds with spray-marked small and large largemouth bass (as in the reservoir experiment). In the remaining two ponds, small and large largemouth bass were finclipped (as in the reservoir experiment). Because these largemouth bass derived from the same group stocked into Clark Lake in fall 1995, we only counted small and large individuals stocked into each pond. On May 15, 1996, we drained ponds over $24 \mathrm{~h}$ and then recovered largemouth bass.

\section{Pool experiments}

To determine how food availability influences overwinter growth and survival of largemouth bass, we conducted an experiment in 2650-L flow-through, aerated outdoor pools at the Aquatic Ecology Laboratory, Ohio State University, in which we fed largemouth bass no food, a low ration, or a high ration $(N=3$ pools/ treatment) during winter 1995-1996. On October 30, 1995, we added 10 largemouth bass/pool (83-143 mm). Each pool contained ten $15-\mathrm{cm}$ pieces of PVC pipe plus sparse leaf litter as shelter. Prey were fathead minnow (mean length $=52 \pm 1 \mathrm{~mm}$, mean weight $=$ $1.4 \pm 0.5 \mathrm{~g}$ ), 36-63\% of largemouth bass lengths. Low ration was $0.5 \times$ the wet weight (grams) estimated by a bioenergetics model for largemouth bass (Hewett and Johnson 1992) necessary to maintain their initial weight during the experiment (depending on temperature, $0.03-0.1 \mathrm{~g} \cdot \mathrm{bass}^{-1} \cdot \mathrm{day}^{-1}$ ); high ration was $1.5 \times$ this maintenance level $\left(0.1-0.3 \mathrm{~g} \cdot \mathrm{bass}^{-1} \cdot \mathrm{day}^{-1}\right)$. Temperatures for these simulations mimicked past winters in pools. Each week, we added sufficient fathead minnow (by wet weight) to provide these rations for the following 7 days. Remaining fathead minnow were removed only once in late December; thereafter, remaining fathead minnow were removed weekly immediately before prey addition. On January 14, March 6, and, finally, May 1, 1996, we partially drained pools, recovered largemouth bass with hand nets, measured and weighed them, and returned them to pools. Although we did not explicitly test for handling effects, survival of largemouth bass was high. In addition, growth in high-ration treatments was high, suggesting that handling effects were negligible (see Results).

\section{Analyses}

For the reservoir survey, we compared changes in length distributions of largemouth bass using a Kolmogorov-Smirnov test. In reservoir and pond experiments, we used $G$-tests to assess the relative loss of small and large largemouth bass by determining if observed relative proportions of marked fish differed from those originally stocked (Sokal and Rohlf 1981). For experiments in winter 1995-1996 in which we quantified energy content of largemouth bass, we compared both total energy content (kilojoules) and energy density (kilojoules per gram wet weight) across treatments with largemouth bass length as the covariate using analysis of covariance (ANCOVA). Because relationships between length and total energy content were power functions, we $\log _{\mathrm{e}}(x)$ transformed both variables before analysis. After adjusting mean responses in ANCOVAs to the same values of the covariate, length (Neter et al. 1990), we used Scheffe's pairwise comparisons to compare differences between spring and fall total kilojoules or kilojoules per gram. For pool experiments, we quantified proportion change of largemouth bass wet weight during three periods: fall, winter, and spring. Pooling results across each feeding treatment, proportion change in weight as a function of length was analyzed using linear regression for each treatment-period combination ( 3 periods $\times 3$ treatments $=9$ comparisons). We also determined if weight change differed from zero using paired $t$-tests. For these nine tests, we adjusted $\alpha$ to protect against type I error $(\alpha / 9=0.05 / 9=0.006$; Miller 1981).

\section{Results}

\section{Temperatures}

Both Pleasant Hill Reservoir (1994-1995) and Clark Lake (1995-1996) temperature recorders were lost. During winter 1994-1995, temperatures in Knox Lake and ponds were similar (Fig. 1A). During winter 1995-1996, temperatures were generally similar among Kokosing Lake and pools, although pools cooled more slowly in fall (Fig. 1B). During December 1995 through March 1996, daily temperatures in ponds were on average $1-2^{\circ} \mathrm{C}$ higher than in pools and Kokosing Lake (Fig. 1B).

\section{Reservoir patterns}

For Knox Lake, the likelihood of a largemouth bass being age-0 declined precipitously from $95 \%$ at $160 \mathrm{~mm}$ to $51 \%$ at $190 \mathrm{~mm}$ (logistic regression, $P<0.05, N=65$ ). Although individuals $<125 \mathrm{~mm}$ comprised about $60 \%$ of the distribution in fall (Fig. 2A), this mode of small largemouth bass declined to $46 \%$ by spring, likely due to their differential mortality (Kolmogorov-Smirnov test, $D=0.18, P<0.05$; Fig. 2B). In Pleasant Hill Reservoir, aging by scales revealed that all of the largemouth bass $\leq 200 \mathrm{~mm}$ likely were age- 0 . Although about $66 \%$ of individuals were $\leq 125 \mathrm{~mm}$ in fall (Fig. 2C), their abundance declined to about $22 \%$ by spring (Kolmogorov-Smirnov test, $D=0.46, P<0.05$; Fig. 2D). Thus, mortality of small individuals appeared higher in Pleasant Hill Reservoir than in Knox Lake during winter 1994-1995.

\section{Reservoir experiments}

In Kokosing Lake, our fall 1995 stocking increased electrofishing catch per unit effort (CPE) to 1.7 largemouth bass/ min shocking. Number of largemouth bass poststocking was $14248 \pm 1597$ (Petersen estimate, mean $\pm 95 \%$ CI), resulting in about 1.9 age-0 largemouth bass $/ \mathrm{m}$ shoreline (resident plus stocked). Relative proportions of small $(<95 \mathrm{~mm})$ and large $(\geq 95 \mathrm{~mm})$ marked largemouth bass captured in Kokosing Lake in fall 1995 did not differ from the initial propor- 
Fig. 1. Mean daily water temperature in Ohio reservoirs (solid line, squares), hatchery ponds (dotted line, circles), and pools (broken line, triangles) during the winters of 1994-1995 and 1995-1996. For clarity, symbols only are plotted for every 10th day. During 1994-1995, reservoir temperatures derive from Knox Lake. During 1995-1996, reservoir temperatures derive from Kokosing Lake. Temperature recorders for other reservoirs were lost during winter.

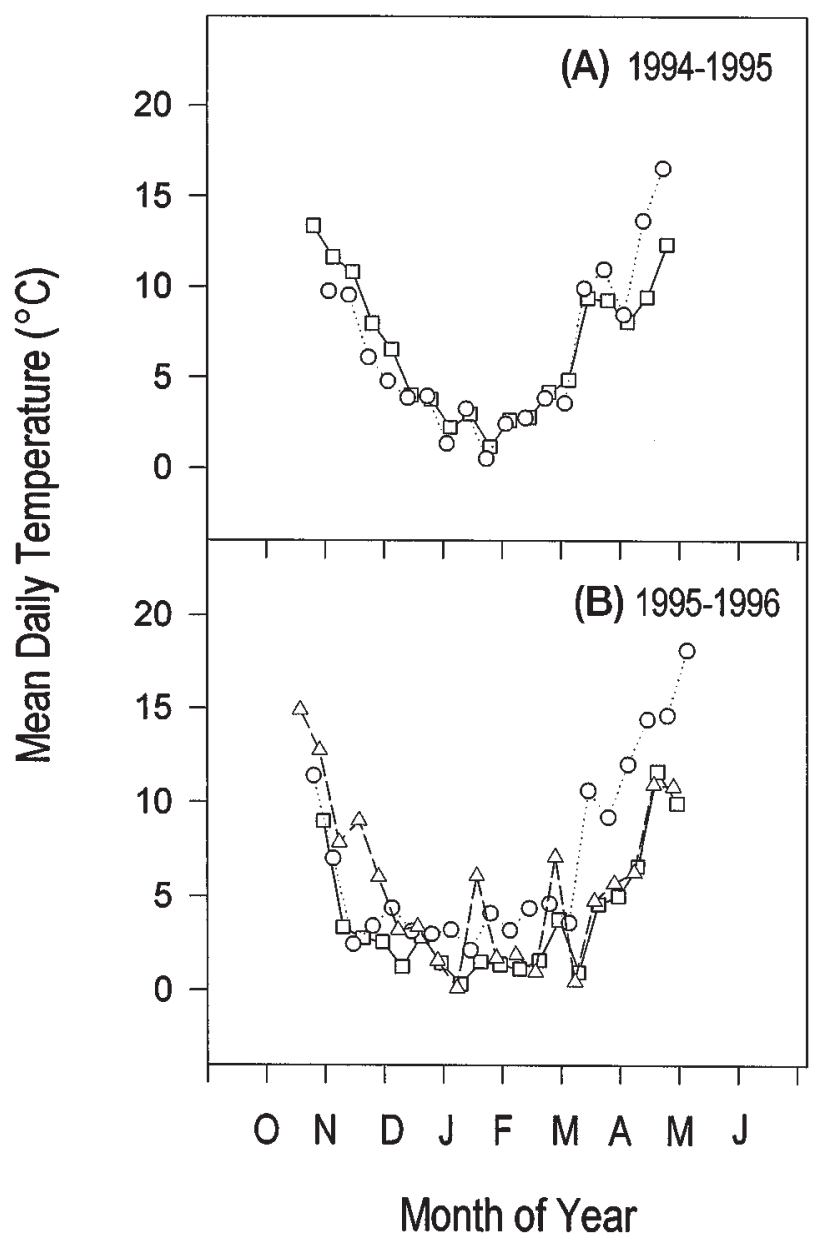

tion stocked a week earlier $(G$-test; $G=2.4, P>0.1$; Fig. 3A; Table 1). In spring 1996, electrofishing CPE declined to nearly 0 . After 4 days of effort, we only captured 23 age-0 largemouth bass. Of these individuals, only 15 were marked, all of which were in the large size class $(G$ test, $P<0.05$; Fig. 3B; Table 1$)$. Both energy density and total energy content of the few recaptured, marked largemouth bass fell considerably from fall values (Scheffe's test, $P<0.05$; Figs. 4A and 4B; Table 2). In fall, large predators were exclusively large largemouth bass (mean length \pm 1 $\mathrm{SD}=207 \pm 39 \mathrm{~mm}, N=33$ ); $82 \%$ of these largemouth bass had consumed fish on the day we sampled, of which $27 \%$ were age-0 largemouth bass. In spring, $71 \%$ of largemouth bass predators $(287 \pm 90 \mathrm{~mm}, N=30)$ consumed fish, although only $3 \%$ contained age- 0 largemouth bass.

Following stocking of Clark Lake in fall 1995, we captured about $8 \%$ fewer small marked largemouth bass than we had stocked a week earlier ( $G$-test, $G=18.9, P<0.05$; Fig. 3C). As in Kokosing Lake, CPE of largemouth bass was
Fig. 2. Proportion of age-0 largemouth bass in each 5-mm length class captured by electrofishing in (A and B) Knox Lake Reservoir and (C and D) Pleasant Hill Reservoir, Ohio, in fall 1994 and spring 1995.

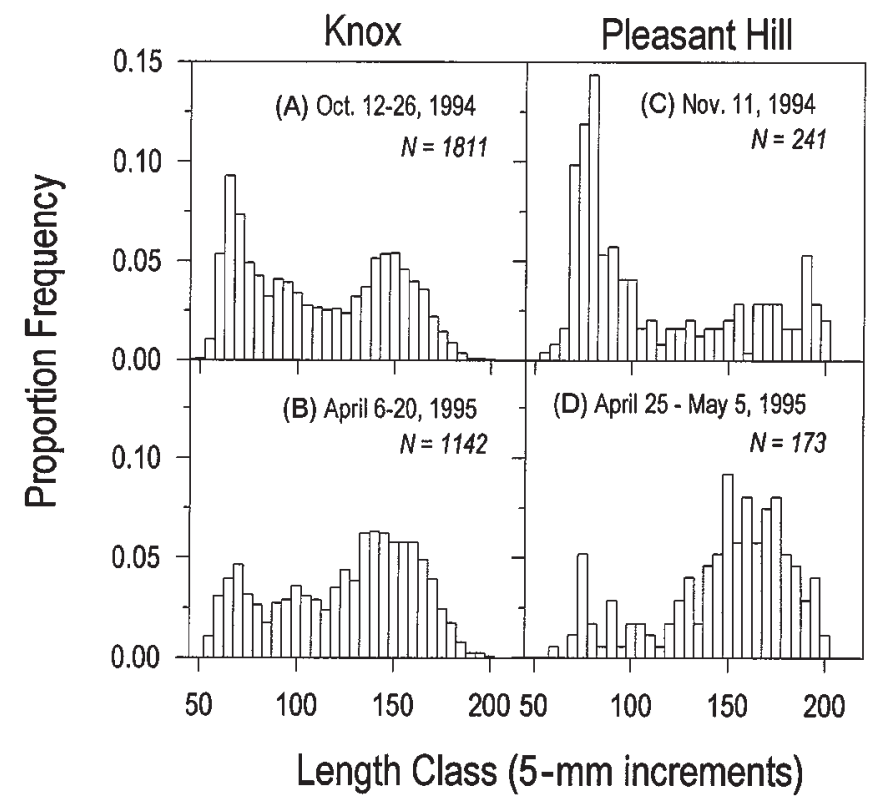

high at 1.1 largemouth bass/min. As indicated by the high CPE, $12623 \pm 1247$ age-0 largemouth bass (Petersen estimate $\pm 95 \%$ CIs) were in Clark Lake, resulting in a higher than anticipated density of 2.8 individuals/m shoreline (resident plus stocked). In spring, CPE fell to 0.2 largemouth bass/min (resident plus stocked individuals), with only 350490 (modified Schnabel estimate; 95\% CI) stocked largemouth bass remaining. Hence, $>95 \%$ of small $(<120 \mathrm{~mm})$ stocked individuals died (Figs. 3C, 3D, and 5A; Table 1). Although mortality was high in Clark Lake, our abundance estimates suggest that more age-0 largemouth bass survived in this system than in Kokosing Lake overwinter. Conversely, survival of large individuals was generally high (Figs. 3C, 3D, and 5A; Table 1). At large sizes, high variance and values exceeding $100 \%$ winter survival likely occurred because some individuals grew from their initial fall size classes (Fig. 5A). As in Kokosing Lake, largemouth bass energy density and total energy content declined through winter (Scheffe's test, $P<0.05$; Figs. 4C and 4D; Table 2). In fall and spring, predators (again exclusively large largemouth bass) were abundant (fall length $272 \pm$ $112 \mathrm{~mm}, N=20$; spring length $309 \pm 39 \mathrm{~mm}, N=54$ ), mostly consuming fish (fall diets $75 \%$ with fish; spring diets $67 \%$ with fish). However, $\leq 5 \%$ of these large predators contained young largemouth bass in fall or spring.

\section{Pond experiments}

Unlike reservoirs, similar proportions of small and large individuals survived in Pond Experiment $\mathrm{A}(N=4$ ponds, Figs. 3E, 3F, and 4B; Table 1). All largemouth bass grew through June (Figs. 3E and 3F), likely by consuming macroinvertebrates and fathead minnow. Apparently, some large (now age 1 year) largemouth bass spawned in May. Hence, small, newly hatched largemouth bass (about $15 \mathrm{~mm}$ ) also were available as forage in late spring. During pond experi- 
Fig. 3. Proportion of total marked largemouth bass in each 5-mm size class in Ohio (A-D) reservoirs (captured by electrofishing) and (E-H) hatchery ponds (stocked into ponds and then recovered by pond draining) during fall 1995 through spring 1996. Actual proportions of individuals in small classes (open bars) and large classes (solid bars) are given in parentheses.

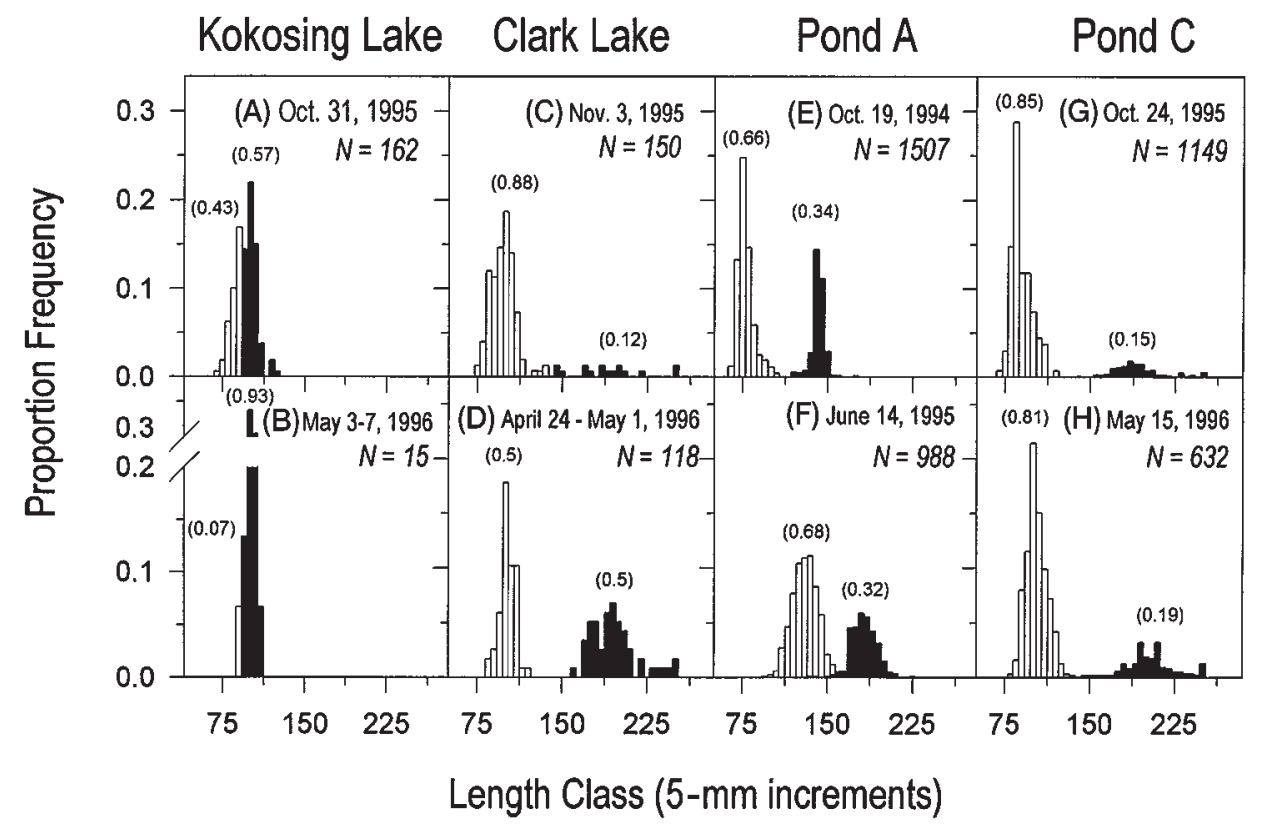

Table 1. Mean \pm 1 SD total length $(\mathrm{mm})$ and relative number of marked small and large largemouth bass stocked in fall and recaptured in spring in Ohio reservoirs and hatchery ponds.

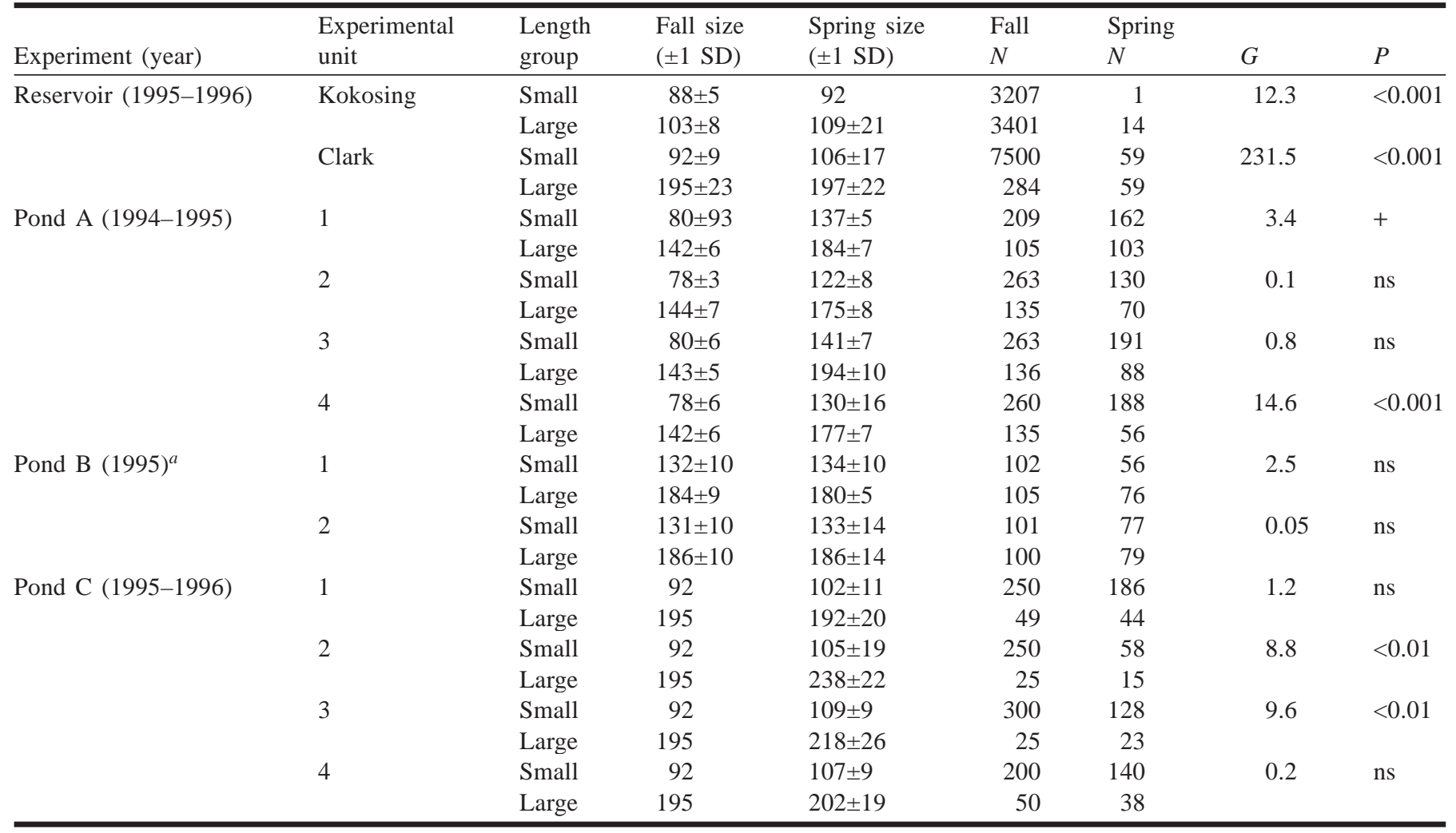

Note: Pond experiments $\mathrm{A}$ and $\mathrm{C}$ were designed to explore the effect of size on overwinter success. Pond experiment B assessed our ability to recover small and large largemouth bass within $24 \mathrm{~h}$ of stocking. Because largemouth bass in pond experiment $\mathrm{C}$ were obtained from the same group stocked into Clark Lake, initial sizes of small and large largemouth bass were the same as those added to Clark Lake. Results of $G$-tests where $P>0.1$ were not significant (ns) and $0.1 \geq P>0.05$ were marginally significant $(+)$.

${ }^{a}$ For pond experiment $\mathrm{B}$, fall and spring refer to numbers stocked and numbers recovered $24 \mathrm{~h}$ later, respectively 
Fig. 4. Energy density and total energy content as a function of total length for largemouth bass in (A-D) reservoir, (E and F) pond, and $(\mathrm{G}$ and $\mathrm{H})$ pool experiments in fall 1995 and spring 1996. Because all largemouth bass originated from the same group of pond largemouth bass in the fall (Figs. 4E and 4F), we compared their spring energy density and total energy content with this initial distribution. Lines on each panel derive from regression models for $\mathrm{kJ} / \mathrm{g}$ wet weight $=\mathrm{mm}$ total length $\times 0.0194+2.367\left(r^{2}=0.33\right.$, $N=40)$ and total $\mathrm{kJ}=3.22 \times 10^{-6} \times \mathrm{mm}^{3.6}\left(r^{2}=0.91, N=40\right)$ for fall largemouth bass (Figs. 4E and 4F). In Figs. 4A-4F, solid circles derive from fall whereas open circles derive from spring. In Figs. $4 \mathrm{G}$ and $4 \mathrm{H}$, open squares, triangles, and inverted triangles represent values from high-, low-, and no-ration treatments in spring, respectively. For largemouth bass $>125 \mathrm{~mm}$ total length, total energy content values were quite high $\left(>4 \times 10^{4}\right)$ and are not included in Figs. 4B, 4D, 4F, and 4H. See Table 2 for statistical comparisons and sample sizes.

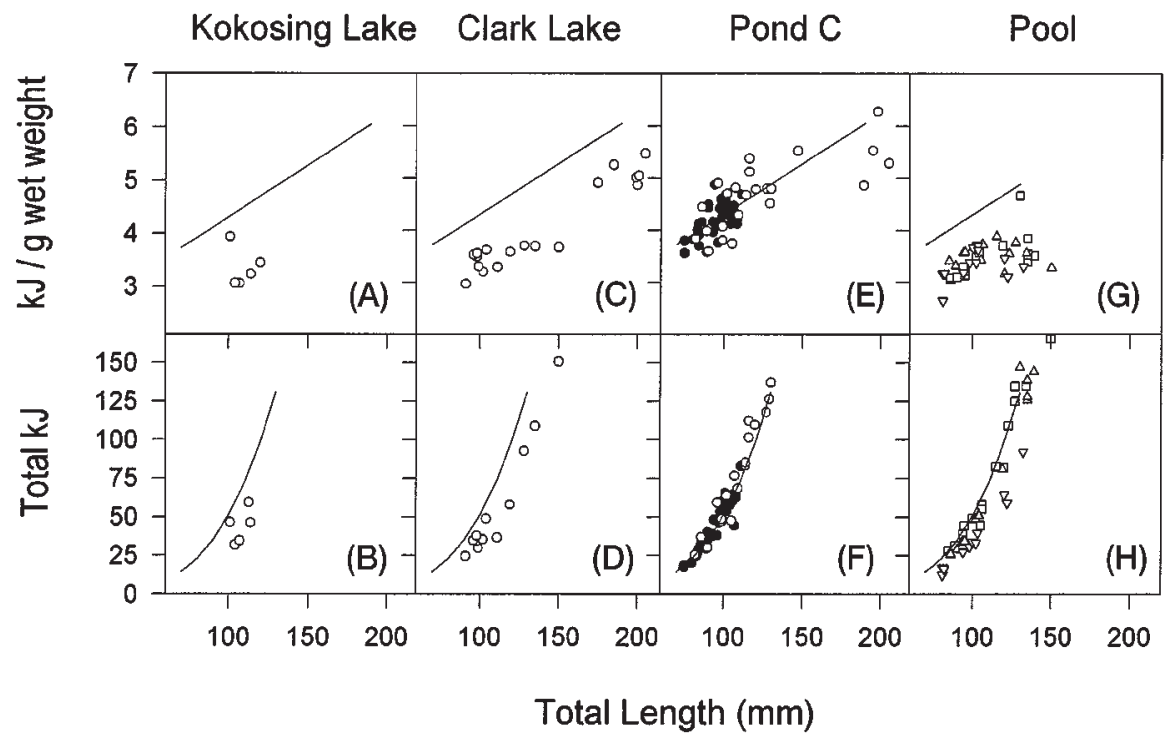

Table 2. Results of Scheffe's multiple comparisons for changes in adjusted mean $\mathrm{kJ} / \mathrm{g}$ wet weight and total $\mathrm{kJ}$ (backcalculated from $\log _{\mathrm{e}}(x)$-transformed data) in multiple-scale experiments during winter 1995-1996.

\begin{tabular}{llcclll}
\hline & & & \multicolumn{3}{c}{ Change } \\
& & \multicolumn{3}{c}{ Change } & & in total \\
Experiment & Treatment & $N$ & in kJ/g & $P$ & kJ & $P$ \\
\hline Reservoir & Kokosing & 5 & -1.1 & $<0.05$ & -19.3 & $<0.05$ \\
& Clark & 13 & -0.93 & $<0.05$ & -10.5 & $<0.05$ \\
Pond C & None & 20 & 0.090 & $\mathrm{~ns}$ & 1.5 & $\mathrm{~ns}$ \\
Pool & High food & 15 & -0.80 & $<0.05$ & -4.2 & $\mathrm{~ns}$ \\
& Low food & 14 & -0.95 & $<0.05$ & -8.2 & $<0.05$ \\
& No food & 12 & -0.96 & $<0.05$ & -18.1 & $<0.05$ \\
\hline
\end{tabular}

Note: Both ANCOVAs for $\mathrm{kJ} / \mathrm{g}$ and total $\mathrm{kJ}$ were significant $(\mathrm{kJ} / \mathrm{g}$ : treatment, $F=43.8, \mathrm{df}=6,111, P<0.05$; length, $F=31.9$, $\mathrm{df}=1,111$, $P<0.05$; total kJ: treatment, $F=35.4$, df $=6,111, P<0.05$; length, $F=$ 1086, $\mathrm{df}=1,111, P<0.05$ ). Differences between adjusted means are spring minus fall, in which all largemouth bass in experiments originated from the same group of fall individuals. Negative values arise when energy density or total kilojoules declined during winter. Differences between adjusted means overlapping zero were not significant (ns, $P>$ 0.05 ). Only largemouth bass $<125 \mathrm{~mm}$ were included in this analysis. See Fig. 4 for graphical presentation.

ment A, we were unable to recapture, on average, about $33 \%$ of largemouth bass originally stocked into ponds (Table 1). In pond experiment $\mathrm{B}$, small and large largemouth bass were equally recoverable ( $G$-test, $P>0.05$; Table 1$)$. However, we were unable to recover a total of $30 \%$ after draining, suggesting that the $33 \%$ loss of individuals in pond experiment A likely was unrelated to winter mortality and due to our inability to recapture all individuals during pond draining.

During winter 1995-1996 in pond experiment C, 23-50\% of largemouth bass were lost in three ponds whereas $77 \%$ were not recovered from pond 2 (Table 1; Figs. $3 \mathrm{G}$ and $3 \mathrm{H}$ ). Retention of both fin clips and spray marks was $>99 \%$ across all ponds and sizes. More small individuals died than large ones in two (ponds 2 and 3 ) of four ponds during winter (Fig. 5C; Table 1), although this loss was slight compared with reservoirs. Interestingly, the two ponds (ponds 2 and 3) with high losses of small individuals also had the greatest size disparity between small and large largemouth bass (Table 1; Fig. 5C). Assuming that largemouth bass $\leq 50 \%$ of the length of conspecifics are vulnerable to cannibalism (Johnson and Post 1996), we calculated the proportion of small largemouth bass vulnerable to average-sized (in length, see Table 1) large largemouth bass in each pond. In ponds 2 and 3 in which size-selective mortality occurred, 95 and $77 \%$ of small largemouth bass were vulnerable versus only 40 and $43 \%$ in ponds 1 and 4 (Fig. 5C). Hence, cannibalism likely contributed to differential mortality in ponds 2 and 3. Without abundant piscine prey and an extended spring in ponds (in contrast, largemouth bass remained in ponds for 1 month longer in pond experiment A), largemouth bass did not grow (Figs. 3G and 3H). Unlike Kokosing and Clark reservoirs, neither largemouth bass energy density nor total energy content changed during winter (Scheffe's test, $P<0.05$; Figs. 4E and 4F; Table 2).

\section{Pool experiments}

Survival in pools was high; only seven of 90 largemouth bass died. When unfed, largemouth bass consistently lost 
Fig. 5. Proportion of largemouth bass surviving (number in spring/number in fall) as a function of mean total length $(\mathrm{mm})$ per size class in (A) Clark Lake, Ohio, during winter 1995-1996 and (B and C) 0.4-ha hatchery ponds ( $N=4$ ponds/year), Hebron State Fish Hatchery, during the winters of 1994-1995 and 1995-1996. Numbers correspond to individual ponds (see Table 1). In spring, the number of largemouth bass in ponds was increased by $30 \%$ to adjust for individuals lost during pond draining.

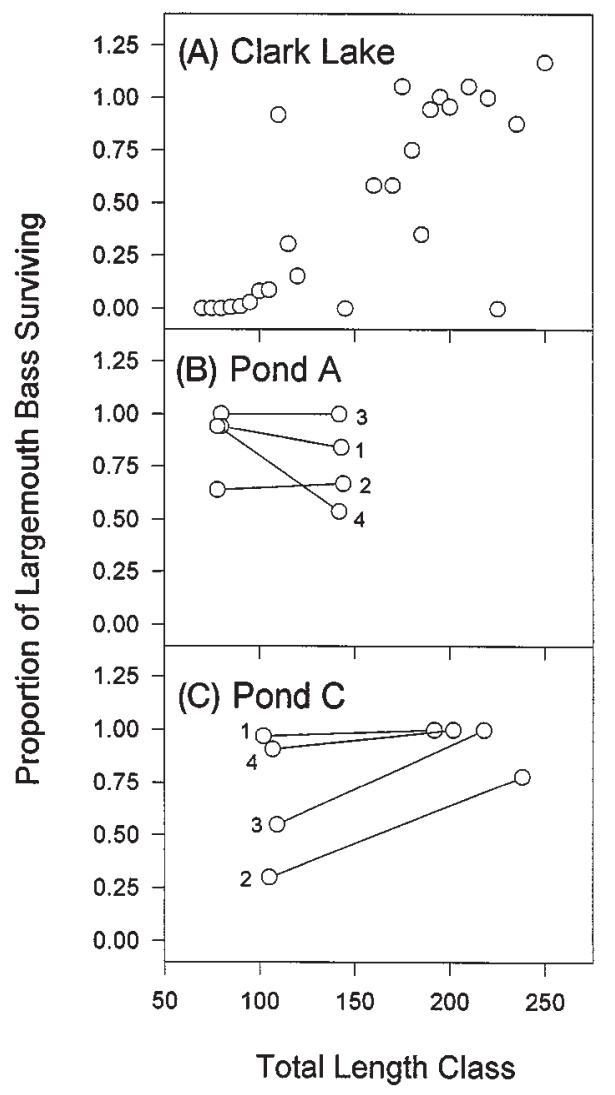

wet weight during fall through spring, regardless of length (paired $t$-test, $P=0.0001$, linear regression, not significant; Figs. 6A-6C). In the low-ration treatment, all fathead minnow were consumed each week during fall (OctoberJanuary) and spring (March-April). Conversely, few fathead minnow were consumed each week during winter (JanuaryMarch) when temperatures were $<6^{\circ} \mathrm{C}$ (see Fig. 1). During fall, large largemouth bass in this low-ration treatment grew more than small counterparts (linear regression, $P=0.003$; Fig. 6D). During winter, largemouth bass of all sizes lost weight (paired $t$-test, $P=0.0001$; Fig. 6E). During spring in this treatment, on average, neither small nor large largemouth bass grew, although growth was quite variable (paired $t$-test, not significant; Fig. 6F). When fed a high ration, all fathead minnow were not consumed weekly, suggesting that this ration provided an excess of prey. All sizes of these high-ration largemouth bass grew during fall and spring (paired $t$-test, $P=0.0001$, linear regression, not significant; Figs. 6G and 6I) but lost weight during winter, even given a surplus of fathead minnow (paired $t$-test, $P=$ 0.0001; Fig. 6H). Despite substantial differences in wet weight change across rations, energy densities of largemouth bass consistently declined through winter for largemouth bass regardless of ration (Scheffe's test, $P<0.05$; Fig. 4G; Table 2). However, total energy content of largemouth bass fed a high ration did not change through winter whereas total energy content declined slightly and severely for largemouth bass with low and no rations, respectively (Fig. 4H; Table 2).

\section{Discussion}

During fall through spring, small fall size always reduced survival of largemouth bass in reservoirs but not in ponds and pools, suggesting that slow first-summer growth may not always translate to poor recruitment to older life stages. Below, we explore how temperature, food availability, and predation potentially interacted to drive these patterns of mortality.

\section{Growth and energy reserves}

For fishes, high mortality should occur when energy reserves (e.g., lipids) are exhausted during winter starvation (e.g., Oliver et al. 1979; Thompson et al. 1991; Ludsin and DeVries 1997). Because lipids are energy dense (Black 1958), we expected that total energy content and energy density of all starving fish would decline during winter, leading to increased mortality of small fish with low initial energy reserves. As expected, all starved largemouth bass in pools lost considerable weight and total energy content, quite similar to patterns of energy depletion in Kokosing and Clark reservoirs. As such, reservoir largemouth bass likely did not feed during winter. Potentially, starvation occurred in reservoirs because stocking greatly increased largemouth bass densities, increasing intraspecific competition for limited food. Although largemouth bass in both pools and reservoirs were starving, high mortality of small individuals only occurred in reservoirs. Thus, energy depletion of starving individuals probably was not the sole factor contributing to patterns of mortality at the reservoir scale.

Although largemouth bass apparently did not feed in reservoirs during winter, variable food availability among systems might influence patterns of energy depletion. The extent of this food-driven variability in energetic condition might be tempered by winter temperature because largemouth bass and smallmouth bass (Micropterus dolomieu) have been suggested to cease feeding at winter temperatures (i.e., $<10^{\circ} \mathrm{C}$ ) and thus should lose weight and energy reserves regardless of food availability (e.g., Johnson and Charlton 1960; Shuter et al. 1980). Contradicting this conventional view, largemouth bass in pools containing fathead minnow fed and grew during a much greater proportion of winter than expected, with growth and consumption only ceasing below $6^{\circ} \mathrm{C}$. Thus, food availability during winter months likely influences patterns of energy depletion across systems.

During winter, prey ration affected growth, as it certainly does during summer (Garvey et al. 1998). Overwinter in pools with $0.5 \times$ ration, largemouth bass slightly increased their wet weight, although surprisingly, both energy density and total energy content declined. With high ration, largemouth bass increased wet weight, even while energy density declined and total energy content remained unchanged. 
Fig. 6. Growth (change in $g$ wet weight/g wet weight at the beginning of each period) as a function of initial total length for largemouth bass in winter 1995-1996 pool experiments with (A-C) no ration, (D-F) low ration, or (G-I) high ration. Fathead minnow were added to pools each week at either $0.5 \times$ (low ration, Figs. 6D-6F) or $1.5 \times$ (high ration, 6G-6I) of largemouth bass maintenance ration as calculated via bioenergetics (Hewett and Johnson 1992). Each point represents an individual largemouth bass $(N=25-30 /$ panel). On each panel, results from linear regression of growth as a function of length (top line) and a paired $t$-test determining if average growth differed from zero (bottom line) are included (for significance, $P \leq 0.006$ ).

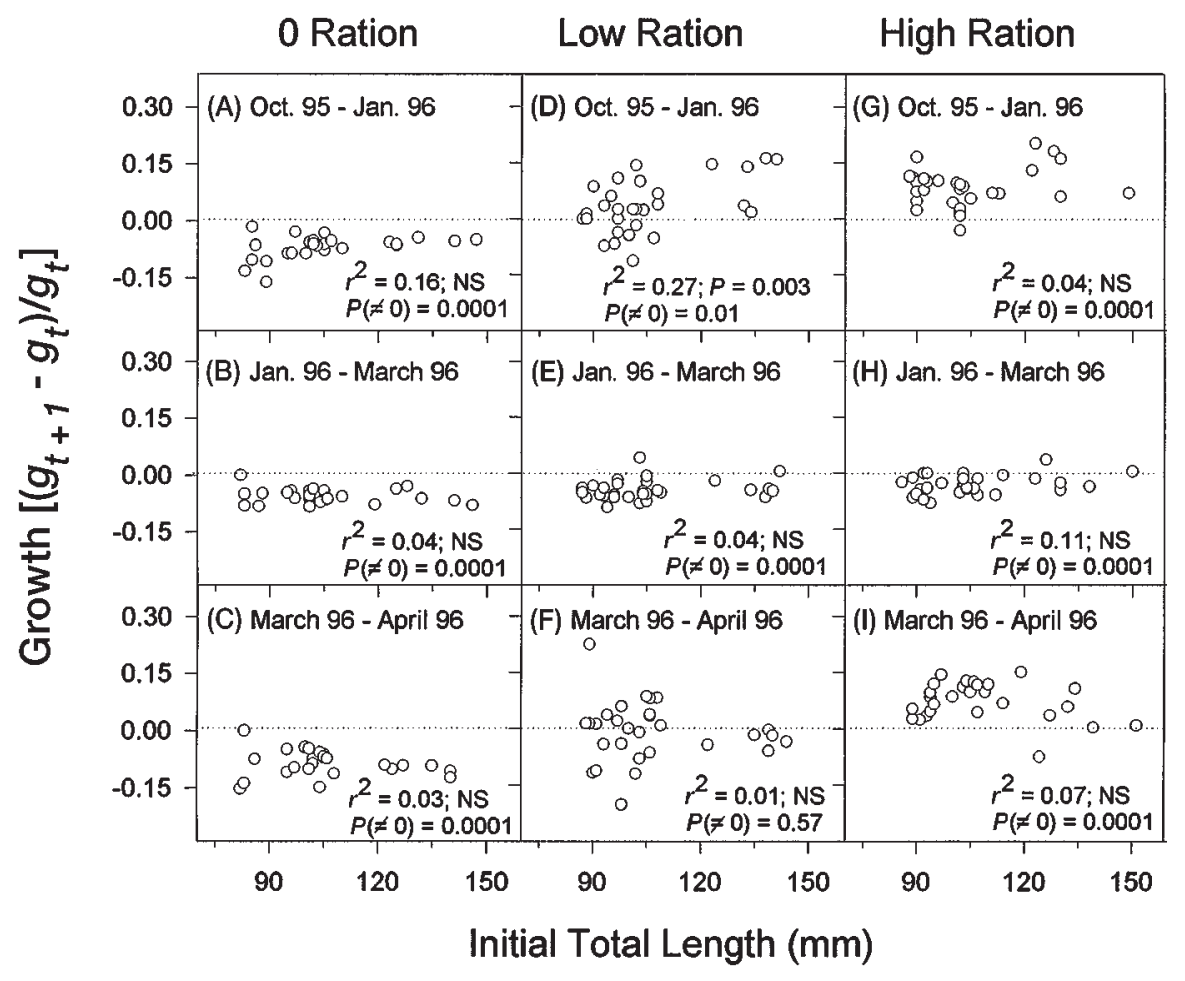

Given these changes, body composition of largemouth bass consuming fathead minnow must have changed during winter, potentially from a high proportion of fat (at $26.3 \mathrm{mg}$ fat $/ \mathrm{kJ}$ ) to a relatively high proportion of protein (at $54.9 \mathrm{mg}$ protein $/ \mathrm{kJ})$. To illustrate, assuming that carbohydrates and other body materials remain relatively constant (Weatherley and Gill 1987), a 5-g (dry weight) individual composed of $20 \%$ protein and $10 \%$ fat will contain the same total energy content (and a higher energy density by dry weight) as a 5.9 -g individual composed of $25 \%$ protein and $5 \%$ fat. Because the proportion of water in tissues increases with declining fat (Niimi 1972), energy density as estimated by kilojoules per gram wet weight should decline even more with increasing protein growth.

In contrast with largemouth bass in pools with fathead minnow, those in ponds without fish prey did not change their weight, energy density, and total energy content during winter. Macroinvertebrates associated with vegetation likely were sufficiently abundant in ponds to allow largemouth bass to maintain weight and energy reserves. Although temperatures in ponds were slightly warmer during winter than in other systems, it is not clear how these warmer temperatures contributed to metabolism, feeding activity, and observed growth. Perhaps differences between the proximate composition of fish prey in pools and macroinvertebrates in ponds influenced allocation patterns and, hence, observed changes in wet weight and energy content. Indeed, proximate composition of prey can dramatically influence protein and fat allocation patterns in cultured fishes (e.g., van Dam and Penning DeVries 1995; Catacutan and Coloso 1995). In summary, growth of feeding largemouth bass during winter was flexible. During fall through spring, actively growing largemouth bass may contain relatively low energy reserves whereas slowly growing fish may be allocating consumed energy toward maintenance of energy reserves. If only one parameter (i.e., length change or energy content) is quantified for either fast-growing or slow-growing fish, one may conclude that condition is poor. Both somatic growth and accumulation of energy reserves must be considered when assessing energetic condition and its potential contribution to survival during winter.

\section{Predation}

If starving largemouth bass suffered similar levels of energy depletion across systems, why was mortality only consistently high for small individuals in reservoirs? In our view, energy depletion in concert with predation by large largemouth bass (Miranda and Hubbard 1994b) or other species (Green 1982) may have contributed to high mortality of small individuals in reservoirs. For example, although Ludsin and DeVries (1997) documented no size-selective predation in Alabama ponds, they postulated that predation risk may force small largemouth bass into shallow-water refuges with little food during winter (S.A. Ludsin, Ohio State University, 1314 Kinnear Rd., Columbus, OH 43212-1194, U.S.A., personal communication). Extreme fluctuations in water temperature in these shallow areas might be energetically costly, accelerating energy depletion. In reservoirs, 
Table 3. Literature review of studies exploring the role of size on overwinter survival of age-0 largemouth bass.

\begin{tabular}{|c|c|c|c|c|}
\hline Source & Latitude & State & Scale of study & $\begin{array}{l}\text { Did large age-0 largemouth } \\
\text { bass enjoy higher survival? }\end{array}$ \\
\hline Ludsin and DeVries 1997 & $33^{\circ}$ & Alabama & 6 ponds & $\operatorname{Yes}^{a}$ \\
\hline Miranda and Hubbard $1994 a$ & $34^{\circ}$ & Mississippi & 1 lake & Yes $^{a}$ \\
\hline Miranda and Hubbard $1994 b$ & $34^{\circ}$ & Mississippi & 26 ponds & Sometimes $^{b}$ \\
\hline Adams et al. 1982 & $36^{\circ}$ & Tennessee & 1 lake & $\operatorname{Yes}^{a}$ \\
\hline Boxrucker 1982 & $36^{\circ}$ & Oklahoma & 1 lake & $\operatorname{Yes}^{a}$ \\
\hline Chang 1971 & $38^{\circ}$ & Missouri & 1 lake & No \\
\hline Isely 1981 & $38^{\circ}$ & Illinois & 5 ponds & No \\
\hline Kohler et al. 1993 & $40^{\circ}$ & Illinois & 2 lakes/6 winters & No \\
\hline This study & $40^{\circ}$ & Ohio & 4 lakes, 8 ponds, 9 pools & Sometimes ${ }^{b}$ \\
\hline Green 1982 & $43^{\circ}$ & New York & 1 lake & Yes $^{b}$ \\
\hline Toneys and Coble 1979 & $43^{\circ}$ & Wisconsin & 1 lake, 1 pond & Sometimes $^{c}$ \\
\hline
\end{tabular}

${ }^{a}$ In these studies, energy depletion due to starvation was implicated as the mechanism underlying differential mortality.

${ }^{b}$ When high mortality of small largemouth bass occurred in these studies, predation was implicated as a potential cause.

${ }^{c}$ In this study, size-selective mortality only occurred at the lake scale, where predators likely were present. Predators were likely absent from the hatchery pond.

small largemouth bass were usually concentrated in shallow water during fall and spring (J.E. Garvey, unpublished data), presumably to avoid predators. Potentially, most small, stocked largemouth bass died in Kokosing Lake either directly through consumption by predators or indirectly through energy depletion in shallow-water refuges. In Clark Lake, in which more small largemouth bass (based on relative CPE) persisted through winter than in Kokosing Lake, direct and indirect effects of predation may have been less intense. Indeed, large largemouth bass consumed mostly non-largemouth-bass prey in fall and spring in Clark Lake.

In ponds and pools, predation was absent, except for two ponds in winter 1995-1996 in which cannibalism may have driven size-selective mortality of small largemouth bass due to the relatively large size disparity between length classes (Johnson and Post 1996). Despite variable food availability in pools and ponds, mortality was generally low and unrelated to size in all other cases. Similarly, in a study exploring how length distributions of fish change through winter, size-selective winter mortality of age-0 largemouth bass occurred in a lake during winter where predators were likely present, but not a in hatchery pond during the same winter (Toneys and Coble 1979). Hence, independently, small fall size may not influence mortality of largemouth bass and perhaps other juvenile fishes during winter. Rather, we hypothesize that predation interacts with fall size and winter food availability to influence growth, survival, and recruitment success (also see Miranda and Hubbard 1994b).

\section{Role of body size revisited}

At present, most models predicting winter survival of fish are based solely on the interactions among winter energetics, body size, and temperature, assuming that negligible feeding occurs at winter temperatures (Shuter et al. 1980; Gutreuter and Anderson 1985; Lyons 1997). These "classic" models predict that survival of small age-0 fish declines with increasing latitude, implicating starvation during long winters as the causal mechanism. From an evolutionary perspective, these models predict that winter only becomes an important selective force at high latitudes (Conover 1990; Conover and Present 1990). Hence, selection for rapid summer growth of age-0 fish should occur at high latitudes as compensation for short first growing seasons (Conover 1990).

To develop population and evolutionary models for species experiencing a wide range of summer and winter conditions, other important interacting factors should be considered. Our reservoir survey and experiments demonstrated that the effects of fall size on winter survival of age- 0 largemouth bass varied across systems under similar winter temperatures and feeding conditions. In addition, the literature revealed that the "classic" model may be incomplete for predicting how first-summer growth influences recruitment (Table 3). In fact, survival of small age-0 largemouth bass relative to large counterparts may generally increase with increasing latitude. At low, southern latitudes, relatively high mortality of small age-0 individuals was common, with energy depletion often implicated as the causal mechanism (Table 3). At these low latitudes, the classic model predicts high survival for both small and large individuals because winter starvation should not occur. At higher latitudes across a similar range of lengths to those in southern systems, survival of small and large age-0 largemouth bass often was similar (Table 3), again contradicting model predictions. Interestingly, in systems where the influence of size on winter survival was mixed, predation was the explanatory mechanism suggested (Green 1982; Miranda and Hubbard 1994b).

Given our results and the apparently contradictory latitudinal pattern, we must modify current simplistic models. Predation, in concert with energy depletion, might be important when $(i)$ winter temperatures are warm and predators are active, as in southern systems (as suggested by Miranda and Hubbard 1994b), (ii) periods of fall cooling and spring warming are long, as in southern and some middle-latitude systems (this study), or (iii) cold-active piscivores (such as 
large percids) are abundant, as in some northern systems (see Green 1982). All of these conditions may increase mortality of age- 0 largemouth bass either directly through active predation or indirectly through increased energy depletion in refuges. Hence, the probability of winter survival and recruitment may be increased by improving firstsummer growth (e.g., by providing abundant, appropriately sized prey fish as forage), improving factors that facilitate winter survival of small individuals (e.g., by providing winter refuge), and fostering growth during fall, winter, and spring months (e.g., by increasing habitat for macroinvertebrate prey and, thus, their availability).

\section{Acknowledgments}

We thank K. Ferry, B. Thompson, A. Fullerton, S. Strong Betz, H. McCann, R. Ginsberg, and S. Micucci for their outstanding efforts in the field and laboratory. Comments by P. Curtis, D. DeVries, E. Marschall, D. Stouder, and two anonymous reviewers on an earlier draft greatly improved this manuscript. We also thank J. Stafford and his staff at the Hebron State Fish Hatchery for their generous support. This research was funded by National Science Foundation grant DEB 9407859 to R.A.S. and Federal Aid in Sport Fish Restoration Project F-69-P, administered jointly by the U.S. Fish and Wildlife Service and the Ohio Division of Wildlife. A Presidential Fellowship from Ohio State University supported J.E.G. during part of this work.

\section{References}

Adams, S.M., and DeAngelis, D.L. 1987. Indirect effects of early bass-shad interactions on predator population structure and food-web dynamics. In Predation: direct and indirect impacts on aquatic communities. Edited by W.C. Kerfoot and A. Sih. University Press of New England, Hanover, N.H. pp. 103-117.

Adams, S.M., McLean, R.B., and Huffman, M.M. 1982. Structuring of a predator population through temperature-mediated effects on prey availability. Can. J. Fish. Aquat. Sci. 39: 11751184.

Aggus, L.R., and Elliott, G.V. 1975. Effects of cover and food on year-class strength of largemouth bass. In Black bass biology and management. Edited by H. Clepper. Sportfishing Institute, Washington D.C. pp. 317-322.

Black, E.C. 1958. Energy stores and metabolism in relation to muscular activity in fishes. In The investigation of fish-power problems. Edited by P.A. Larkin. University of British Columbia, Vancouver, B.C.

Boxrucker, J. 1982. First year growth and survival of stocked largemouth bass in a small Oklahoma impoundment. Proc. Annu. Conf. Southeast. Assoc. Fish Wild. Agencies, 36: 369376.

Bremigan, M.T., and Stein, R.A. 1994. Predator gape and zooplankton size: exploring a size-dependent recruitment mechanism in fishes. Can. J. Fish. Aquat. Sci. 51: 913-922.

Cargnelli, L.M., and Gross, M.R. 1996. The temporal dimension in fish recruitment: birth date, body size, and size-dependent survival in a sunfish (bluegill: Lepomis macrochirus). Can. J. Fish. Aquat. Sci. 53: 360-367.

Catacutan, M.R., and Coloso, R.M. 1995. Effect of dietary protein to energy ratios on growth, survival, and body composition of juvenile Asian seabass, Lates calcarifer. Aquaculture, 131: 125133.
Chang, K.B. 1971. Population characteristics of largemouth bass and bluegill in a Missouri pond with an evaluation of some sampling methods. M.A. thesis, University of Missouri, Columbia, Mo.

Christensen, B. 1996. Predator foraging capabilities and prey antipredator behaviours: pre- versus postcapture constraints on sizedependent predator-prey interactions. Oikos, 76: 368-380.

Conover, D.O. 1990. The relation between capacity for growth and length of growing season: evidence for and implications of countergradient variation. Trans. Am. Fish. Soc. 119: 416-430.

Conover, D.O., and Present, T.M.C. 1990. Countergradient variation in growth rate: compensation for length of the growing season among Atlantic silversides from different latitudes. Oecologia, 83: 316-324.

Feinberg, S.E. 1980. The analysis of cross-classified categorical data. The MIT Press, Cambridge, Mass.

Garvey, J.E., and Stein, R.A. 1998. Linking bluegill and gizzard shad prey assemblages to growth of age- 0 largemouth bass in reservoirs. Trans. Am. Fish. Soc. 127: 70-83.

Garvey, J.E., Dingledine, N.A., Donovan, N.S., and Stein, R.A. 1998. Exploring spatial and temporal variation within reservoir food webs: predictions for fish assemblages. Ecol. Appl. 8: 104 120.

Green, D.M. 1982. Population dynamics of largemouth bass (Micropterus salmoides) and chain pickerel (Esox niger) in Dryden Lake, New York. Ph.D. dissertation, Cornell University, Ithaca, N.Y.

Gutreuter, S.J., and Anderson, R.O. 1985. Importance of body size to the recruitment process in largemouth bass. Trans. Am. Fish. Soc. 114: 317-327.

Hambright, K.D., Drenner, R.W., McComas, S.R., and Hairston, N.G., Jr. 1991. Gape-limited piscivores, planktivore size refuges, and the trophic cascade hypothesis. Arch. Hydrobiol. 121: 389-404.

Hewett, S.W., and Johnson, B.L. 1992. Fish bioenergetics model 2, an upgrade of a generalized bioenergetics model of fish growth for microcomputers. University of Wisconsin Sea Grant Institute, Madison, Wis.

Holland-Bartels, L.E., Littlejohn, S.K., and Huston, M.L. 1990. A guide to the larval fishes of the upper Mississippi River. U.S. Fish and Wildlife Service, LaCrosse, Wis.

Isely, J.J. 1981. Effects of water temperature and energy reserves on overwinter mortality of young-of-year largemouth bass (Micropterus salmoides). M.S. thesis, Southern Illinois University, Carbondale, Ill.

Johnson, M.G., and Charlton, W.H. 1960. Some effects of temperature on the metabolism and activity of the largemouth bass, Micropterus salmoides, Lacepede. Prog. Fish-Cult. 22: 155-163.

Johnson, J.M., and Post, D.M. 1996. Morphological constraints on intracohort cannibalism in age-0 largemouth bass. Trans. Am. Fish. Soc. 125: 809-812.

Kohler, C.C., Sheehan, R.J., and Sweatman, J.J. 1993. Largemouth bass hatching success and first-winter survival in two Illinois reservoirs. N. Am. J. Fish. Manage. 13: 125-133.

Kolander, T.D. 1992. Factors limiting overwinter survival of young-of-the-year largemouth bass in South Dakota. M.S. thesis, South Dakota State University, Brookings, S.D.

Ludsin, S.A., and DeVries, D.R. 1997. Understanding first-year survival of a freshwater piscivore: the inter-dependency of lifehistory stages. Ecol. Appl. 7: 1024-1038.

Lyons, J. 1997. Influence of winter starvation on the distribution of smallmouth bass among Wisconsin streams: a bioenergetics modeling assessment. Trans. Am. Fish. Soc. 126: 157-162. 
May, R.C. 1974. Larval mortality in marine fishes and the critical period concept. The early life history of fishes. Springer-Verlag, New York.

Miller, R.P. 1981. Simultaneous statistical inference. 2nd ed. Springer Verlag, New York.

Miller, T.J., Crowder, L.B., Rice, J.A., and Marschall, E.A. 1988. Larval size and recruitment mechanisms in fishes: toward a conceptual framework. Can. J. Fish. Aquat. Sci. 45: 1657-1670.

Miranda, L.E., and Hubbard, W.D. 1994a. Length-dependent winter survival and lipid composition of age-0 largemouth bass in Bay Springs Reservoir, Mississippi. Trans. Am. Fish. Soc. 123: 80-87.

Miranda, L.E., and Hubbard, W.D. 1994b. Winter survival of age-0 largemouth bass relative to size, predators and shelter. N. Am. J. Fish. Manage. 14: 790-796.

Neter, J., Wasserman, W., and Kutner, M.H. 1990. Applied linear statistical models: regression, analysis of variance, and experimental designs. Irwin, Boston, Mass.

Nielsen, L.A. 1992. Methods of marking fish and shellfish. Am. Fish. Soc. Spec. Publ. No. 23.

Niimi, A.J. 1972. Changes in the proximate body composition of largemouth bass (Micropterus salmoides) with starvation. Can. J. Zool. 50: 815-819.

Oliver, J.D., Holeton, G.F., and Chua, K.E. 1979. Overwinter mortality of fingerling smallmouth bass in relation to size, relative energy stores, and environmental temperature. Trans. Am. Fish. Soc. 108: 130-136.

Post, J.R., and Evans, D.O. 1989. Size-dependent overwinter mortality of young-of-year yellow perch (Perca flavescens): laboratory, in situ enclosure, and field experiments. Can. J. Fish. Aquat. Sci. 46: 1958-1968.

Rand, P.S., Lantry, B.F., O'Gorman, R., Owens, R.W., and Stewart, D.J. 1994. Energy density and size of pelagic prey fishes in Lake Ontario, 1978-1990: implications for salmonine energetics. Trans. Am. Fish. Soc. 123: 519-534.

Rice, J.A., Crowder, L.B., and Binkowski, F.P. 1987. Evaluating potential sources of mortality for larval bloater (Coregonus hoyi): starvation and vulnerability to predation. Can. J. Fish. Aquat. Sci. 44: 467-472.
Ricker, W.E. 1975. Computation and interpretation of biological statistics of fish populations. Bull. Fish. Res. Board Can. No. 191.

SAS Institute, Inc. 1985. SAS users guide: statistics. Version 5 edition. SAS Institute Inc., Cary, N.C.

Schael, D.M., Rudstam, L.G., and Post, J.R. 1991. Gape limitation and prey selection in larval yellow perch (Perca flavescens), freshwater drum (Aplodinotus grunniens), and black crappie (Pomoxis nigromaculatis). Can. J. Fish. Aquat. Sci. 48: 19191925.

Seaburg, 1957. A stomach sampler for live fish. Prog. Fish-Cult. 19: $137-139$.

Shirley, K.E., and Andrews, A.K. 1977. Growth, production, and mortality of largemouth bass during the first year of life in Lake Carl Blackwell, Oklahoma. Trans. Am. Fish. Soc. 106: 590-595.

Shuter, B.J., MacLean, J.A., Fry, F.E.J., and Regier, H.A. 1980. Stochastic simulation of temperature effects on first-year survival of smallmouth bass. Trans. Am. Fish. Soc. 109: 1-34.

Sokal, R.R., and Rohlf, F.J. 1981. Biometry: the principles and practice of statistics in biological research. W.H. Freeman and Company, New York.

Thompson, J.M., Bergarson, E.P., Carlson, C.A., and Keading, L.R. 1991. Role of size, condition, and lipid content in the overwinter survival of age-0 Colorado squawfish. Trans. Am. Fish. Soc. 120: 346-353.

Toneys, M.L., and Coble, D.W. 1979. Size-related, first winter mortality of freshwater fishes. Trans. Am. Fish. Soc. 108: 415419.

van Dam, A.A., and Penning DeVries, F.W.T. 1995. Parameterization and calibration of a model to simulate effects of feeding level and feed composition on growth of Oreochromis niloticus (L.) and Oncorhynchus mykiss (Walbaum). Aq. Res. 26: 415425.

Weatherley, A.H., and Gill, H.S. 1987. The biology of fish growth. Academic Press, New York.

Wright, R.A. 1993. Size dependence of growth, consumption, and survival in juvenile largemouth bass: combining experimental manipulation and individual-based simulation. Ph.D. dissertation, University of Wisconsin, Madison, Wis. 